\title{
Mechanisms of the stimulation of insulin release by oxytocin in normal mouse islets
}

\author{
Zhi-Yong GAO, Gisela DREWS and Jean-Claude HENQUIN* \\ Unité de Diabétologie et Nutrition, University of Louvain Faculty of Medicine, Avenue Hippocrate 54, \\ UCL 54.74, B-1200 Brussels, Belgium
}

\begin{abstract}
Oxytocin (OT) produced a dose-dependent increase in somatostatin, glucagon and insulin release by isolated mouse islets. A small effect on somatostatin release was observed with 0.1 nM-OT, but 1-10 nM-OT was required to affect A- and Bcells significantly. The effects of OT on somatostatin and glucagon release were similar in the presence of $3 \mathrm{~mm}-$ and $10 \mathrm{~mm}$-glucose. No change in insulin release was produced by OT in $3 \mathrm{~mm}$-glucose, but a stimulation was still observed in the presence of a maximally effective concentration of glucose $(30 \mathrm{mM})$. The increase in insulin release produced by OT (in $15 \mathrm{~mm}$-glucose) was accompanied by small accelerations of ${ }^{86} \mathrm{Rb}$ and ${ }^{45} \mathrm{Ca}$ efflux from islet cells. Omission of extracellular $\mathrm{Ca}^{2+}$ accentuated the effect of OT on ${ }^{86} \mathrm{Rb}$ efflux, attenuated that on ${ }^{45} \mathrm{Ca}$ efflux, and abolished that on release. OT never inhibited ${ }^{86} \mathrm{Rb}$ efflux. It did not affect the resting potential of $\mathrm{B}$-cells, but slightly increased the $\mathrm{Ca}^{2+}$-dependent electrical activity induced by 15 mM-glucose. OT did not affect cyclic AMP levels, but increased inositol phosphate levels in islet cells. It is suggested that the amplification of glucose-induced insulin release that OT produces is due to a stimulation of phosphoinositide metabolism, and presumably an activation of protein kinase $\mathrm{C}$, rather than to a change in cyclic AMP levels or a direct action on the membrane potential. Since OT is present in the pancreas, it is possible that it exerts a neuropeptidergic control of the islet function.
\end{abstract}

\section{INTRODUCTION}

Besides its major physiological effects on the uterus and mammary gland, oxytocin (OT) exerts several metabolic actions. Changes in plasma concentrations of glucose and fatty acids have been noted after OT administration [1-4]. It has also been reported that OT increases plasma levels of insulin and glucagon in animals [5-9] and in man [10,11].

Studies in vivo have established that OT modulates lipolysis in adipocytes [12], increases glycogenolysis in hepatocytes [13], and directly affects hormone release by the endocrine pancreas. OT was found to increase glucagon and insulin secretion by the isolated and perfused rat pancreas [14] and glucagon secretion by isolated and incubated rat islets [15]. The mechanisms of these stimulatory effects of OT are, however, unknown. Though surprising at first sight, the possibility that OT plays a role in the control of the endocrine pancreas is supported by the recent biochemical demonstration of the presence of OT in the pancreas [16], by the immunohistochemical detection of OT in nerve terminals in the islets [17], and by the identification of OT receptors in islet cells [18].

The present study is an investigation of the mechanisms by which OT affects hormone release by normal mouse islets.

\section{MATERIALS AND METHODS}

All experiments were performed with islets of fed female NMRI mice (25-30 g), killed by decapitation. For electrophysiological experiments, a piece of pancreas was fixed in a perifusion chamber and islets were partially microdissected by hand. The membrane potential of single B-cells was continuously recorded with high-resistance microelectrodes [19]. B-cells were identified by the typical electrical activity that they display in the presence of $15 \mathrm{~mm}$-glucose.
For all other experiments, islets were isolated after collagenase digestion of the pancreas. After isolation, the islets were loaded with ${ }^{45} \mathrm{Ca}$ or ${ }^{86} \mathrm{Rb}$ (used as tracer for $\mathrm{K}^{+}$) during $90 \mathrm{~min}$ of incubation in $0.25 \mathrm{ml}$ of medium containing $15 \mathrm{~mm}$-glucose. The islets were then washed and placed in batches of 25-30 in perifusion chambers [20]. The radioactivity lost by the islets was measured in effluent fractions collected at 2 min intervals, and the fractional efflux rate was calculated for each period. A portion of each effluent fraction was taken for insulin assay. Release of insulin, glucagon and somatostatin was also measured in incubation experiments. After $60 \mathrm{~min}$ of preincubation in a medium containing $15 \mathrm{~mm}$-glucose, batches of seven islets were incubated for $60 \mathrm{~min}$ in $1 \mathrm{ml}$ of medium containing $3 \mathrm{~mm}$ - or $10 \mathrm{~mm}$-glucose and supplemented with OT (0.001-100 nM). A portion of the medium was withdrawn and appropriately diluted at the end of the incubation. Insulin was measured by a doubleantibody radioimmunoassay with rat insulin as standard (Novo Research Institute, Bagsvaerd, Denmark). Glucagon and somatostatin were measured by a radioimmunoassay using a dextran-coated-charcoal separation step [21].

For measurement of inositol phosphate levels, islets were first loaded with myo- $\left[2-{ }^{3} \mathrm{H}\right]$ inositol for $2 \mathrm{~h}$. Free inositol and inositol phosphates were separated by anion-exchange chromatography [22]. Details of the technique have been reported recently [23]. Islet cyclic AMP concentrations were determined by radioimmunoassay with a commercially available kit (Du PontNew England Nuclear, Boston, MA, U.S.A.) after acetylation of samples [23,24].

The basal medium used was a bicarbonate-buffered solution which contained $120 \mathrm{~mm}-\mathrm{NaCl}, 4.8 \mathrm{~mm}-\mathrm{KCl}, 2.5 \mathrm{~mm}-\mathrm{CaCl}_{2}$, $1.2 \mathrm{~mm}-\mathrm{MgCl}_{2}$ and $24 \mathrm{~mm}-\mathrm{NaHCO}_{3}$. It was gassed with $\mathrm{O}_{2} / \mathrm{CO}_{2}$ (47:3), had a $\mathrm{pH}$ of 7.4 at $37^{\circ} \mathrm{C}$, and, except for electrophysiological experiments, was supplemented with BSA (1 $\mathrm{mg} / \mathrm{ml})$.

OT was obtained from Peninsula Laboratories (Belmont, CA,

Abbreviation used: OT, oxytocin

* To whom reprint requests should be addressed. 
U.S.A.). The same batch was used for all experiments. Forskolin was from Calbiochem-Behring (San Diego, CA, U.S.A.). Radiochemicals were purchased from The Radiochemical Centre (Amersham, Bucks., U.K.).

Electrophysiological experiments are illustrated by a recording that is representative of the indicated number of experiments. atherwise, results are presented as means \pm S.E.M. for the indicated numbers of experiments (different animals or islet preparations) or batches of islets. The statistical significance of differences between means was assessed by comparing control and test conditions (electrophysiological experiments) by a paired $t$ test, or by analysis of variance followed by a Dunnett test. Differences were considered significant at $P<0.05$.

\section{RESULTS}

\section{Effects of OT on hormone release by incubated islets}

Somatostatin release by control islets was 2.4 -fold higher in the presence of $10 \mathrm{mM}$-glucose than in the presence of $3 \mathrm{mM}$-glucose
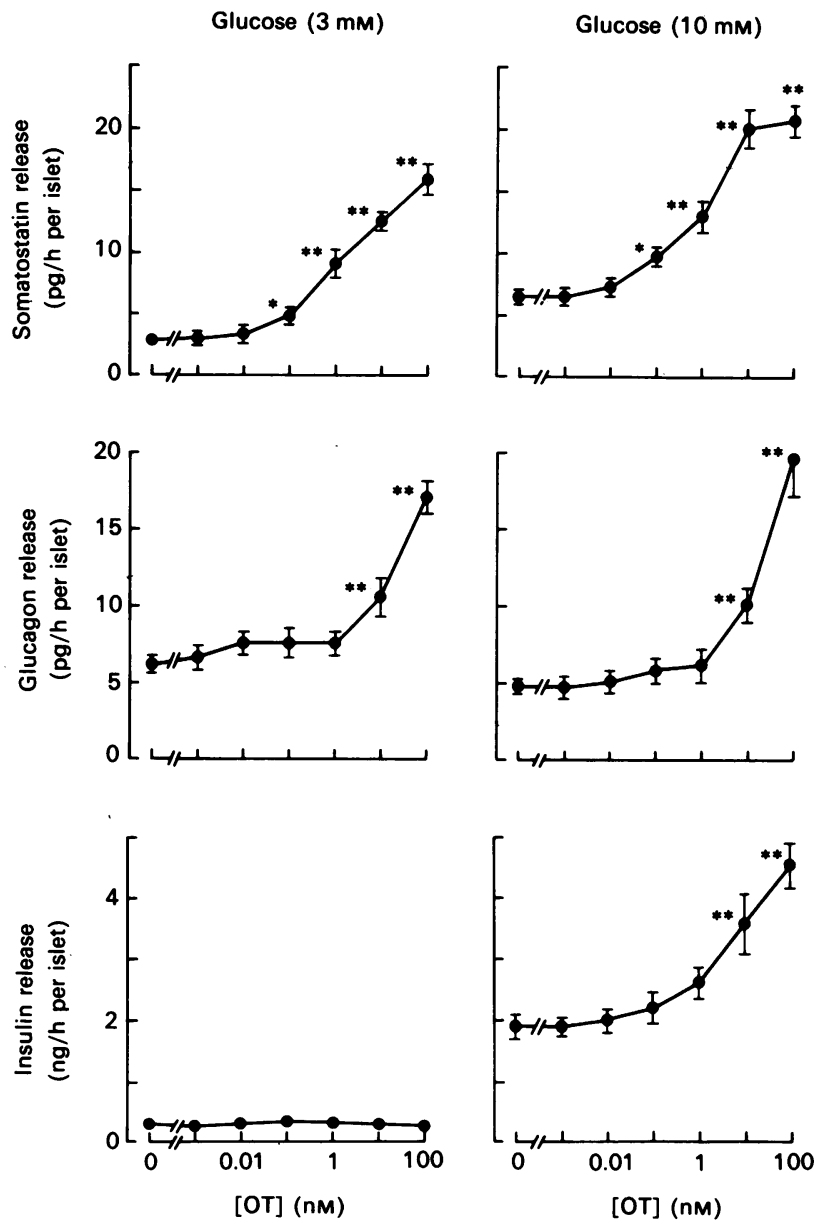

Fig. 1. Effects of various concentrations of OT on release of somatostatin, glucagon and insulin from mouse islets

Batches of seven islets were incubated for $60 \mathrm{~min}$ in $1 \mathrm{ml}$ of medium containing $3 \mathrm{~mm}$ - or $10 \mathrm{~mm}$-glucose, and supplemented with the indicated concentration of OT. Values are means \pm S.E.M. for $10-15$ batches of islets from at least five different experiments: ${ }^{*} P<0.05$ and ${ }^{* *} P<0.01$ versus controls without OT.
(6.4 \pm 0.3 versus $2.7 \pm 0.3 \mathrm{pg} / \mathrm{h}$ per islet; $P<0.001)$. OT produced a dose-dependent increase in somatostatin release at both glucose concentrations (Fig. 1). The lowest effective concentration of OT was $0.1 \mathrm{nM}$. In $10 \mathrm{~mm}$-glucose, the half-maximal response was observed at about $1 \mathrm{nM}-\mathrm{OT}$.

Glucagon release by control islets was only marginally lower in $10 \mathrm{~mm}$ - than in $3 \mathrm{~mm}$-glucose $(4.8 \pm 0.4$ versus $6.2 \pm 0.6 \mathrm{pg} / \mathrm{h}$ per islet; $P=0.05$ ); the major inhibition (by about $60 \%$ ) occurs between 0 and $3 \mathrm{~mm}$-glucese. OT (10 and $100 \mathrm{~nm}$ ) increased glucagon release, and this effect was similar at both glucose concentrations.

Insulin release by control islets was stimulated 6.3 -fold by $10 \mathrm{~mm}$-glucose compared with $3 \mathrm{~mm}$-glucose $(1.9 \pm 0.2$ versus $0.3 \pm 0.04 \mathrm{ng} / \mathrm{h}$ per islet; $P<0.001)$. OT did not affect insulin release in $3 \mathrm{~mm}$-glucose, but increased it in the presence of $10 \mathrm{~mm}$-glucose. The $39 \%$ increase produced by $1 \mathrm{nM}-\mathrm{OT}$ almost reached statistical significance $(0.05<P<0.1)$. Separate experiments showed that $1 \mu \mathrm{M}$-OT was not more effective than $100 \mathrm{nM}$-OT $(2.3 \pm 0.4 \mathrm{ng} / \mathrm{h}$ per islet in $10 \mathrm{~mm}$-glucose alone, and $4.9 \pm 0.7$ and $5.0 \pm 0.6 \mathrm{ng} / \mathrm{h}$ per islet in the presence of $100 \mathrm{nM}$ and $1 \mu \mathrm{M}-\mathrm{OT}$ respectively; means \pm S.E.M.; $n=10$ ). One may thus tentatively estimate a half-maximally effective concentration of about $5 \mathrm{nM}$-OT in $10 \mathrm{~mm}$-glucose. The maximal effect of OT was also observed at $100 \mathrm{~nm}$ in the presence of $15 \mathrm{~mm}$-glucose $(8.3 \pm 0.6 \mathrm{ng} / \mathrm{h}$ per islet in $15 \mathrm{~mm}$-glucose alone, and $16.3 \pm 0.9$ and $17.0 \pm 1.0 \mathrm{ng} / \mathrm{h}$ per islet in the presence of $100 \mathrm{nM}$ - and $1 \mu \mathrm{M}$ OT respectively; means \pm S.E.M.; $n=25$ ).

\section{Effects of OT on insulin release and ionic fluxes in perifused islets}

OT (100 nM) increased ${ }^{45} \mathrm{Ca}$ efflux, ${ }^{86} \mathrm{Rb}$ efflux and insulin release from islets perifused with a medium containing $15 \mathrm{~mm}$ glucose and $2.5 \mathrm{~mm}-\mathrm{Ca}^{2+}$ (Fig. 2). The accelerations of ${ }^{45} \mathrm{Ca}$ efflux and ${ }^{86} \mathrm{Rb}$ efflux rapidly stabilized and were thus of small amplitude, whereas the increase in insulin release did not reach a plateau until after $20 \mathrm{~min}$ of stimulation with OT. All these changes were reversible on withdrawal of OT.

When the medium did not contain $\mathrm{Ca}^{2+}$, insulin release was not stimulated by glucose and was not increased by $100 \mathrm{nM}-\mathrm{OT}$, which, however, still accelerated ${ }^{45} \mathrm{Ca}$ and ${ }^{86} \mathrm{Rb}$ efflux (Fig. 3). The increase in ${ }^{45} \mathrm{Ca}$ efflux was most marked during the first minutes of stimulation, but subsequently faded out. On the other hand, the increase in ${ }^{86} \mathrm{Rb}$ efflux was sustained and was clearly larger than in the presence of $\mathrm{Ca}^{2+}$.

${ }^{86} \mathrm{Rb}$ efflux was also measured in the presence of $3 \mathrm{~mm}$-glucose. The slow decrease in the efflux rate that occurs under these conditions was unaffected by $100 \mathrm{nM}-\mathrm{OT}: 2.40 \pm 0.05 \% / \mathrm{min}$ at $40 \mathrm{~min}, 2.04 \pm 0.02 \% / \mathrm{min}$ at $70 \mathrm{~min}$ in control islets, and $2.08 \pm 0.07 \% / \mathrm{min}$ in islets stimulated by $100 \mathrm{nM}-\mathrm{OT}$ since $40 \mathrm{~min}$ $(n=5)$. OT was also without effect on insulin release by these islets perifused with a medium containing only $3 \mathrm{~mm}$-glucose (results not shown).

In the presence of a maximally effective concentration of glucose $(30 \mathrm{mM})$, the rate of insulin release averaged $336 \pm 53 \mathrm{pg} / \mathrm{min}$ per islet. It increased to $634 \pm 75 \mathrm{pg} / \mathrm{min}$ per islet $(n=4)$ after $30 \mathrm{~min}$ of stimulation with $100 \mathrm{nM}-\mathrm{OT}$.

\section{Effects of OT on the membrane potential of B-cells}

The resting membrane potential of B-cells perifused with a medium containing 3 mM-glucose was not affected by $100 \mathrm{nM}-\mathrm{OT}$ $(-60 \pm 4 \mathrm{mV}$ without OT versus $-61 \pm 3 \mathrm{mV}$ with OT; $n=3$ ).

In the presence of $15 \mathrm{~mm}$-glucose, B-cells were depolarized and exhibited a rhythmic electrical activity, consisting of slow waves of the membrane potential with $\mathrm{Ca}^{2+}$ spikes superimposed on the plateau (Fig. 4). OT (100 nM) had little effect on this electrical 

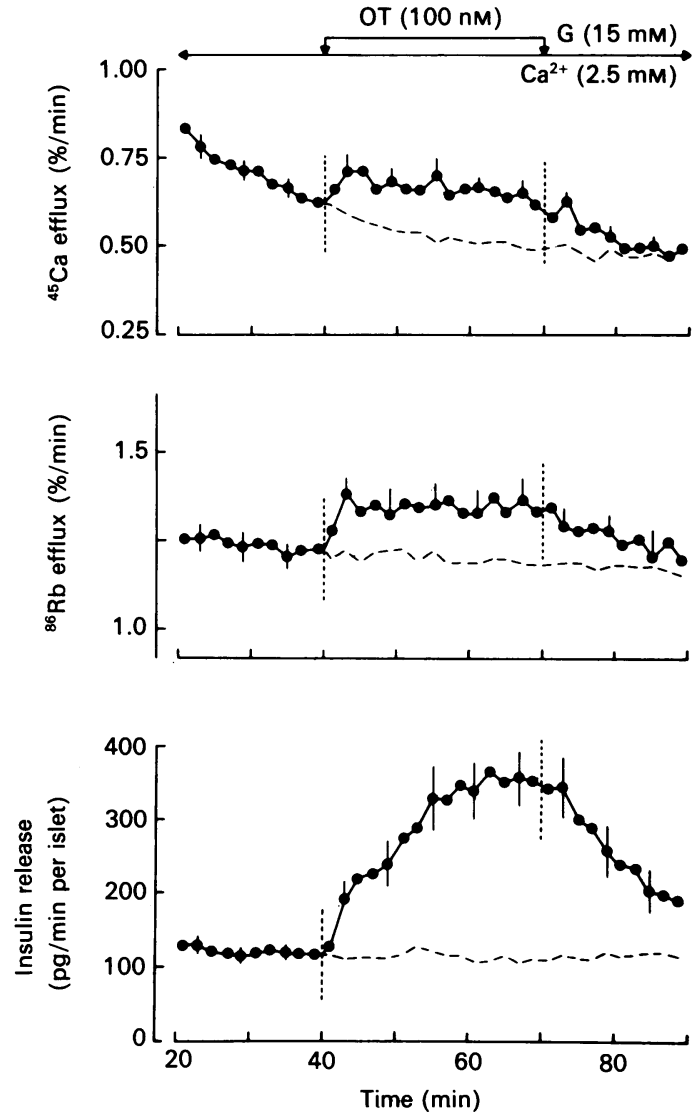

Fig. 2. Effects of OT on ${ }^{45} \mathrm{Ca}$ efflux, ${ }^{86} \mathrm{Rb}$ efflux and insulin release from mouse islets perifused with a medium containing 15 mM-glucose (G) and $2.5 \mathrm{mM}-\mathrm{Ca}^{2+}$

OT (100 nM) was added between 40 and $70 \mathrm{~min}$. Control experiments without OT are shown by the broken lines. Values are means \pm S.E.M. for four to six experiments.

activity. The lower panels summarize the quantification of the effects of OT after 6 or 16 min of application. The duration of the slow waves with spikes was not modified by OT, but that of the intervals slightly decreased. The frequency of the slow waves slightly increased. The net effect on the overall electrical activity was a small increase in the plateau phase (percentage of time with spike activity) (Fig. 4).

\section{Effects of OT on inositol phosphate and cyclic AMP levels}

Inositol phosphate levels were measured in islets which were preincubated with myo-[2- $\left.{ }^{3} \mathrm{H}\right]$ inositol to label their phosphoinositides, and then stimulated by $100 \mathrm{nM}-\mathrm{OT}$ in a medium containing $5 \mathrm{~mm}-\mathrm{LiCl}$ (Table 1). OT significantly increased the levels of $\operatorname{Ins} P_{1}, \operatorname{Ins} P_{2}$ and $\operatorname{Ins} P_{3}$.

In contrast with forskolin, $100 \mathrm{nM}-\mathrm{OT}$ did not increase islet cyclic AMP levels (Table 1), but both agents potentiated insulin release.

\section{DISCUSSION}

The present study establishes that OT stimulates somatostatin release, confirms that OT increases glucagon and insulin release, and demonstrates that a stimulation of phosphoinositide meta-
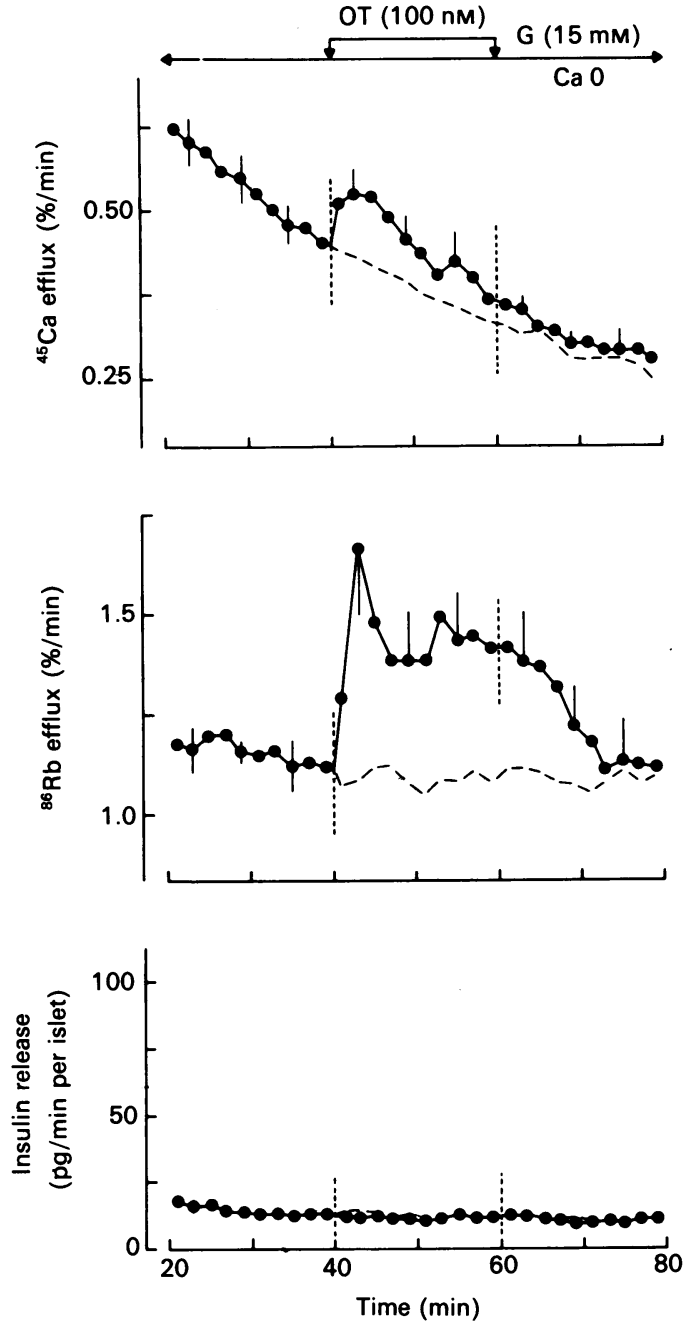

Fig. 3. Effects of OT on ${ }^{45} \mathrm{Ca}$ efflux, ${ }^{86} \mathrm{Rb}$ effilux and insulin release from mouse islets perifused with a $\mathrm{Ca}^{2+}$-free medium containing $15 \mathrm{mM}$ glucose (G)

OT ( $100 \mathrm{nM}$ ) was added between 40 and $60 \mathrm{~min}$. Control experiments without OT are shown by the broken lines. Values are means \pm S.E.M. for four to five experiments.

bolism rather than a change in ionic fluxes, membrane potential or cyclic AMP underlies the effects of OT in B-cells. The interpretation of the results is based on the widely accepted assumption that biochemical or ionic changes measured in whole islets are representative of the changes occurring in B-cells, which make up $70-80 \%$ of the islet population.

In experiments using isolated rat islets or the perfused rat pancreas, Dunning et al. observed that OT stimulated glucagon release, but had little effect on insulin release [14,15]. This difference in the sensitivity of A- and B-cells to OT was not observed in the present study. Of the three islet cell types, D-cells appear to be the most sensitive to OT in the mouse, but the differences are not very marked. In the presence of $10 \mathrm{~mm}$ glucose, the estimated half-maximally effective concentrations of OT were $1 \mathrm{nM}$ (D-cells) and $5 \mathrm{~nm}$ (B-cells). These values correspond well to the affinity of OT receptors $\left(K_{d} 1-5 \mathrm{nM}\right)$ in other tissues [25].

The effectiveness of OT on somatostatin release in $3 \mathrm{~mm}$ glucose may seem surprising. It should, however, be recalled that the threshold glucose concentration for stimulation of D-cells is lower than that for stimulation of B-cells $[26,27]$. In our system 

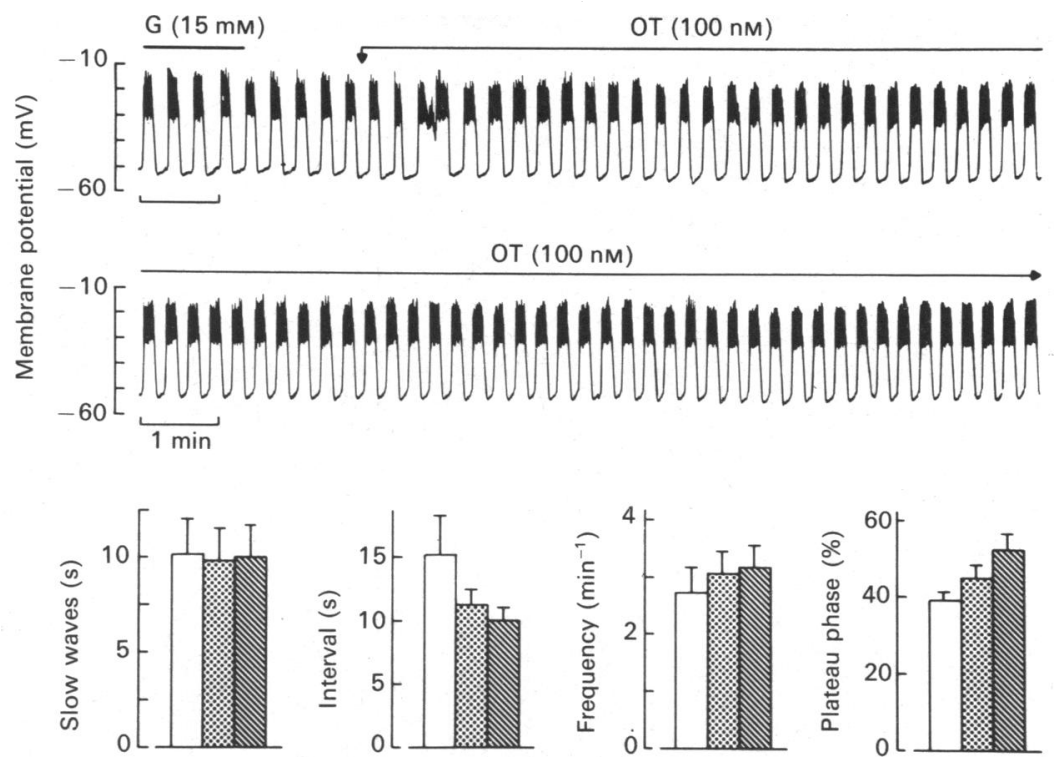

Fig. 4. Effects of OT on the membrane potential of mouse pancreatic B-cells perifused with a medium containing 15 mM-glucose (G) and 2.5 mM-Ca ${ }^{2+}$

OT (100 nM) was added as indicated by the arrows. The lower recording is the direct continuation of the upper one. The lower panels show the quantitative changes (means \pm S.E.M.) in electrical activity in four similar experiments (different mice). All slow waves and intervals were measured during the last $4 \mathrm{~min}$ of perifusion with glucose alone ( $\square$ ), and during the periods 6-10 min (粼) and 16-20 min ( OT. The plateau phase is the percentage of time spent at the plateau potential with spike activity.

Table 1. Effects of oxytocin on inositol phosphate and cyclic AMP levels in mouse islets

For measurement of inositol phosphate levels, the islets were first preincubated for $120 \mathrm{~min}$ in a medium containing $15 \mathrm{~mm}$-glucose and supplemented with $m y o-\left[{ }^{3} \mathrm{H}\right]$ inositol. They were then washed and subdivided in batches of $40-50$. For measurements of cyclic AMP levels, the islets were first preincubated for $60 \mathrm{~min}$ in a medium containing $15 \mathrm{mM}$-glucose. They were then subdivided in batches of 10 . Each batch of islets was eventually incubated for $60 \mathrm{~min}$ in a medium containing $15 \mathrm{~mm}$-glucose. When tested, oxytocin and forskolin were added for the last 30 min of incubation only. In the experiments designed to measure islet cyclic AMP levels, the incubation medium was saved for measurement of insulin release. Values are means \pm S.E.M. for 5 batches of islets (inositol phosphates), or for 12 or 18 batches of islets (cyclic AMP): ${ }^{*} P<0.01$ versus controls (by analysis of variance followed by Dunnett's test).

\begin{tabular}{|c|c|c|c|c|c|}
\hline \multirow[b]{2}{*}{ Experimental conditions } & \multicolumn{3}{|c|}{ Content (d.p.m./islet) } & \multirow{2}{*}{$\begin{array}{l}\text { Cyclic AMP } \\
\text { (fmol/islet) }\end{array}$} & \multirow{2}{*}{$\begin{array}{l}\text { Insulin release } \\
\text { (ng/h per islet) }\end{array}$} \\
\hline & $\operatorname{Ins} P_{1}$ & Ins $P_{2}$ & Ins $P_{3}$ & & \\
\hline $\begin{array}{l}\text { Controls } \\
\text { Oxytocin (100 nM) } \\
\text { Forskolin (100 nM) }\end{array}$ & $\begin{array}{c}69 \pm 4 \\
411 \pm 24^{*} \\
-\end{array}$ & $\begin{array}{l}42 \pm 4 \\
60 \pm 4^{*} \\
-\end{array}$ & $\begin{array}{l}32 \pm 1 \\
39 \pm 3^{*} \\
-\end{array}$ & $\begin{array}{l}22.0 \pm 1.2 \\
22.3 \pm 1.2 \\
52.5 \pm 3.6^{*}\end{array}$ & $\begin{array}{c}6.5 \pm 0.4 \\
9.3 \pm 0.4^{*} \\
13.5 \pm 0.9^{*}\end{array}$ \\
\hline
\end{tabular}

3 mM-glucose slightly increases somatostatin release compared with zero glucose, whereas insulin release is unaffected (Z.-Y. Gao \& J.-C. Henquin, unpublished work).

The maximum concentrations of somatostatin and glucagon reached in the medium at the end of the incubations with $100 \mathrm{nM}$ OT were between 0.01 and $0.1 \mathrm{nM}$. These concentrations are too low to affect insulin release by intact islets [28]. It is thus unlikely that the stimulation of somatostatin and glucagon release by OT markedly influences the B-cell response, except if substantially higher concentrations exist within the islets.

$\mathrm{K}^{+}$channels of the B-cell membrane, in particular the ATPsensitive $\mathrm{K}^{+}$channels, are a major target for agents modulating insulin release $[29,30]$. Their closure, e.g. by glucose or sulphonylureas, underlies the depolarization that activates $\mathrm{Ca}^{2+}$ channels and eventually triggers release. Several arguments make it possible to exclude the hypothesis that the effects of OT result from a closure of these channels. Firstly, OT neither inhibited ${ }^{86} \mathrm{Rb}$ efflux from islet cells nor depolarized the B-cell membrane in the presence of $3 \mathrm{~mm}$-glucose. Secondly, OT accelerated ${ }^{86} \mathrm{Rb}$ efflux from islets perifused with $15 \mathrm{~mm}$-glucose, in both the absence and the presence of extracellular $\mathrm{Ca}^{2+}$, whereas, at this glucose concentration, agents which block ATP-sensitive $\mathrm{K}^{+}$ channels would increase ${ }^{86} \mathrm{Rb}$ efflux in the presence of $\mathrm{Ca}^{2+}$ but decrease it in the absence of $\mathrm{Ca}^{2+}[31,32]$. Thirdly, the small increase in electrical activity produced by OT in B-cells perifused with a medium containing $15 \mathrm{~mm}$-glucose was not characterized by a lengthening of the slow waves like that produced by higher concentrations of glucose or by sulphonylureas [33]. On the other hand, the small increase in slow-wave frequency secondary to the shortening of the intervals, which OT produced, closely resembles the effect of various activators of protein kinase C [34,35]. A further similarity is the paradoxically larger acceleration of ${ }^{86} \mathrm{Rb}$ efflux in the absence than in the presence of extracellular $\mathrm{Ca}^{2+}$. A conservative conclusion is thus that the small effects of OT on the membrane potential are mediated by an activation of protein kinase $\mathrm{C}$.

The results show that OT both increased $\mathrm{Ca}^{2+}$ influx and mobilized intracellular $\mathrm{Ca}^{2+}$ in $\mathrm{B}$-cells, but that the potentiation of insulin release required the presence of extracellular $\mathrm{Ca}^{2+}$. That OT causes a small increase in $\mathrm{Ca}^{2+}$ influx is indicated by two 
observations. Firstly, OT accelerated ${ }^{45} \mathrm{Ca}$ efflux more markedly in the presence than in the absence of extracellular $\mathrm{Ca}^{2+}$. Secondly, glucose-induced electrical activity, which reflects $\mathrm{Ca}^{2+}$ influx in B-cells [32], was slightly augmented by OT. It is thus possible that a small increase in $\mathrm{Ca}^{2+}$ influx contributes to the effects of OT on insulin release, but there is no doubt that other mechanisms are involved. The combination of $15 \mathrm{~mm}$-glucose and OT increased insulin release to a similar rate as in the presence of $30 \mathrm{~mm}$-glucose alone, although the plateau phase of electrical activity was still below $60 \%$, compared with $100 \%$ in $30 \mathrm{~mm}$ glucose [33].

The small increase in ${ }^{45} \mathrm{Ca}$ efflux that OT consistently caused in islets perifused with a $\mathrm{Ca}^{2+}$-free medium indicates that OT mobilizes intracellular $\mathrm{Ca}^{2+}$ in B-cells. No insulin release occurred simultaneously, probably because this mobilization was of too small magnitude. In experiments using various concentrations of acetylcholine, it was observed that insulin release in the absence of $\mathrm{Ca}^{2+}$ increases only when $\mathrm{Ca}^{2+}$ mobilization exceeds a certain threshold [36]. This threshold, attained with $10 \mu \mathrm{M}$-acetylcholine, was not reached during the stimulation by OT, the effect of which is similar to that of $1 \mu \mathrm{M}$-acetylcholine.

Stimulation of phosphoinositide metabolism by OT has been observed in the classical target tissues of the hormone, the uterus [37-39] and the mammary gland [40], and in adipocytes [41]. That OT also stimulated phosphoinositide turnover in B-cells is indicated by the increases in the levels of labelled $\operatorname{Ins} P_{1}, \operatorname{Ins} P_{2}$ and Ins $P_{3}$ that it produced in islets prelabelled with myo- $\left[{ }^{3} \mathrm{H}\right]$ inositol. Although the isomer of $\operatorname{Ins} P_{3}$ cannot be identified with the technique used [22], the results are compatible with the hypothesis that the mobilization of intracellular $\mathrm{Ca}^{2+}$ is due to the production of $\operatorname{Ins}(1,4,5) P_{3}$. It also seems reasonable to assume that diacylglycerol was produced concomitantly with the production of inositol phosphates [42], and that the activation of protein kinase $\mathrm{C}$ ensued. That an activation of protein kinase $\mathrm{C}$ participates in the increase in insulin release brought about by OT is in keeping with the lack of effect of OT in low glucose, with the persistence of its effect in the presence of a maximally effective concentration of the sugar, and with the requirement of extracellular $\mathrm{Ca}^{2+}[34,36,43]$.

OT has been reported to increase cyclic AMP levels in LLC$\mathrm{PK}_{1}$ kidney epithelial cells, an effect possibly mediated by $\mathrm{V}_{2}-$ vasopressin receptors [44]. No effect of OT was observed on cyclic AMP levels in islet cells. Our data therefore support the concept that OT receptors are not coupled to adenylate cyclase.

In conclusion, OT potently amplifies glucose-induced insulin release in normal mouse islets. This effect appears to involve a stimulation of phosphoinositide metabolism with its consequences on $\mathrm{Ca}^{2+}$ movements and on activation of protein kinase $\mathrm{C}$. The results also show that OT increases somatostatin and glucagon release, but cannot prove that this increase is underlain by the same mechanisms. This hypothesis would, however, be compatible with the reports that activation of protein kinase $\mathrm{C}$ by phorbol esters induces glucagon release by pancreatic A-cells [45] and somatostatin release by gastric D-cells [46]. The effects of OT on the endocrine pancreas resemble those of vasopressin, which was recently shown to amplify insulin release by stimulating phosphoinositide metabolism in B-cells $[23,47]$. This similarity raises the question of whether both peptides exert their action by activating the same or distinct receptors [48]. We note, however, that both OT and [arginine]vasopressin have been identified in the pancreas of several species [17] and that they might thus have a local neuropeptidergic function.

This work was supported by grant 3.4607 .90 from the FRSM, Brussels, and by grant SPPS-AC 89/95-135 from the Ministry of Scientific Policy,
Brussels. J.-C.H. is 'Directeur de recherches' of the FNRS, Brussels. We thank M. Gérard for skilled assistance and M. Nenquin for editorial help.

\section{REFERENCES}

1. Mirsky, I. A. (1962) Proc. Soc. Exp. Biol. Med. 110, 42-44

2. Heidenreich, O., Kook, Y. \& Reus, E. (1962) NaunynSchmiedeberg's Arch. Pharmacol. 234, 136-147

3. Burt, R. L., Leake, N. H. \& Dannenburg, W. N. (1964) Nature (London) 201, 829-830

4. Balasse, E. \& Rasio, E. (1965) Arch. Int. Pharmacodyn. 157, 356-359

5. Kaneto, A. \& Kosaka, K. (1970) Endocrinology (Baltimore) 87, 439-444

6. Altszuler, N. \& Hampshire, J. (1981) Diabetes 30, 112-114

7. Knudtzon, J. (1983) Horm. Metab. Res. 15, 103-104

8. Vilhardt, H., Krarup, T., Holst, J. J. \& Bie, P. (1986) J. Endocrinol. 108, 293-298

9. Stock, S. \& Uvnäs-Moberg, K. (1987) Acta Physiol. Scand. 130, 55-61

10. Chiodera, P., Coiro, V., Camellini, L., Rossi, G., Pignatti, D., Volpi, R. \& Roti, E. (1984) Horm. Res. 20, 150-154

11. Paolisso, G., Sgambato, S., Passariello, N., Torella, R., Giugliano, D., Mignano, S., Varricchio, M. \& D'Onofrio, F. (1988) Horm. Res. 30, $10-16$

12. Muchmore, D. B., Little, S. A. \& de Haën, C. (1981) J. Biol. Chem. 256, 365-372

13. Hems, D. A. Rodrigues, L. M. \& Whitton, P. D. (1978) Biochem. J. 172, 311-317

14. Dunning, B. E., Moltz, J. H. \& Fawcett, C. P. (1984) Peptides 5, 871-875

15. Dunning, B. E., Moltz, J. H. \& Fawcett, C. P. (1984) Am. J. Physiol. 246, E108-E114

16. Amico, J. A., Finn, F. M. \& Haldar, J. (1988) Am. J. Med. Sci. 296, 303-307

17. McDonald, J. K., Greiner, F., Wood, J. G. \& Noe, B. D. (1987) Cell Tissue Res. 249, 7-12

18. Stock, S., Fastbom, J., Björkstrand, E., Ungerstedt, U. \& UvnäsMoberg, K. (1990) Regul. Peptides 30, 1-13

19. Meissner, H. P. \& Schmelz, H. (1974) Pflügers Arch. 407, 195206

20. Henquin, J. C. (1979) Nature (London) 280, 66-68

21. Herbert, V., Lau, K. S., Gottlieb, W. S. \& Blecker, S. J. (1965) J. Clin. Endocrinol. Metab. 25, 1375-1384

22. Berridge, M. J., Dawson, R. M. C., Downes, C. P., Heslop, J. P. \& Irvine, R. F. (1983) Biochem. J. 196, 771-780

23. Gao, Z. Y., Drews, G., Nenquin, M., Plant, T. D. \& Henquin, J. C. (1990) J. Biol. Chem. 265, 15724-15730

24. Henquin, J. C. (1981) Biochem. J. 196, 771-780

25. Jard, S., Elands, J., Schmidt, A. \& Barberis, C. (1988) in Progress in Endocrinology 1988 (Imura, H., ed.), pp. 1183-1188, Elsevier Science Publishers, Amsterdam

26. Gerber, P. P. G., Trimble, E. R., Wollheim, C. B., Renold, A. E. \& Miller, R. E. (1981) Diabetes 30, 40-44

27. Sorensen, R. L. \& Elde, R. P. (1983) Diabetes 32, 561-567

28. Pipeleers, D. G., Schuit, F. C., in't Veld, P. A., Maes, E., HooghePeeters, E. L., van de Winkel, M. \& Gepts, W. (1985) Endocrinology (Baltimore) 117, 824-833

29. Ashford, M. L. J. (1990) in Potassium Channels: Structure, Classification, Function and Therapeutic Potential (Cook, N. S., ed.), pp. 300-325, Ellis Horwood, Chichester

30. Ashcroft, F. M. \& Rorsman, P. (1991) Prog. Biophys. Mol. Biol., in the press

31. Henquin, J. C. \& Meissner, H. P. (1982) Biochem. Pharmacol. 31, $1407-1415$

32. Henquin, J. C. \& Meissner, H. P. (1984) Experientia 40, 1043-1052

33. Henquin, J. C. (1988) Biochem. Biophys. Res. Commun. 156, 769-775

34. Bozem, M., Nenquin, M. \& Henquin, J. C. (1987) Endocrinology (Baltimore) 121, 1025-1033

35. Henquin, J. C., Schmeer, W., Nenquin, M. \& Plant, T. D. (1989) Diabetologia 32, 496A (abstr.)

36. Garcia, M. C., Hermans, M. P. \& Henquin, J. C. (1988) Biochem. J. 254, 211-218 
37. Marc, S., Leiber, D. \& Harbon, S. (1986) FEBS Lett. 201, 9-14

38. Flint, A. P. F., Leat, W. M. F., Sheldrick, E. L. \& Stewart, H. J. (1986) Biochem. J. 237, 797-805

39. Schrey, M. P., Read, A. M. \& Steer, P. J. (1987) Biochem. J. 246, 705-713

40. Zhao, X. \& Gorewit, R. C. (1987) Neuropeptides 10, 227-233

41. Augert, G. \& Exton, J. H. (1988) J. Biol. Chem. 263, 3600-3609

42. Berridge, M. J. \& Irvine, R. F. (1989) Nature (London) 341, 197-205

43. Persaud, S. J., Jones, P. M., Sugden, D. \& Howell, S. L. (1989) Biochem. J. 264, 753-758

Received 27 December 1990/30 January 1991; accepted 4 February 1991
44. Leitman, D. C., Agnost, V. L., Catalano, R. M., Schröder, H., Waldman, S. A., Bennett, B. M., Tuan, J. J. \& Murad, F. (1988) Endocrinology (Baltimore) 122, 1478-1485

45. Hii, C. S. T., Stutchfield, J. \& Howell, S. L. (1986) Biochem. J. 233, 287-289

46. Sugano, K., Park, J., Soll, A. \& Yamada, T. (1986) Am. J. Physiol. 250, G686-G690

47. Richardson, S. B., Eyler, N., Twente, S., Monaco, M., Altszuler, N. \& Gibson, M. (1990) Endocrinology (Baltimore) 126, 1047-1052 48. Jard, S. (1988) Kidney Int. 34, S38-S42 